\title{
Success factors for the development of process technology in process industry: Part 2: a ranking of success factors on an operational level and a dynamic model for company implementation
}

\section{Thomas Lager*}

Centre for Management of Innovation and Technology

in Process Industry, Luleå University of Technology,

SE-97187 Luleå, Sweden

E-mail: thomas.lager@ies.luth.se

${ }^{*}$ Corresponding author

\section{Sven-Åke Hörte}

Department of Business Administration and Social Sciences, Division of Industrial Organization, Luleå University of Technology, SE-97187 Luleå, Sweden E-mail: sven-ake.horte@set.hh.se

\begin{abstract}
In a research project on the development of process technology in process industry, success factors have been developed and ranked by R\&D managers in various sectors of European process industry. The results are presented in two parts, of which this is Part 2 of the study. A new classification system for success factors in R\&D was developed as an introduction in Part 1, and the discussion in this paper presents a model for company implementation. The empirical research results give an emerging picture of a development area, a development process and a type of development behaviour that differ markedly from product development and the product development process. The results can also be seen as a shopping list and a starting point for in-company development of success factors and performance indicators for process development.
\end{abstract}

Keywords: process industry; process technology; process development; success factors.

Reference to this paper should be made as follows: Lager, T. and Hörte, S.A. (2005) 'Success factors for the development of process technology in process industry: Part 2: a ranking of success factors on an operational level and a dynamic model for company implementation', Int. J. Process Management and Benchmarking, Vol. 1, No. 1 pp.104-126.

Biographical notes: Thomas Lager is an adjunct professor and director of the Centre for Management of Innovation and Technology in Process Industry (PROMOTe) at the Luleå University of Technology in Sweden. He is president of $B \& L$ Innovation, a consulting firm specialising in $R \& D$ Management. He holds an MS degree in Mining Engineering from the Royal Institute of Technology, Sweden, a $\mathrm{PhD}$ in Mineral Processing and a $\mathrm{PhD}$ in Business Administration and Economics from the Luleå University of Technology, Luleå. Lager has also served 15 years in the process industry, mainly in the capacities of Production Engineer and R\&D Manager. 
Sven Åke Hörte is a professor in Industrial Organisation in the Department of Business Administration and Social Sciences at the Luleå University of Technology and professor in Sociology at Halmstad University. He holds a $\mathrm{PhD}$ in Sociology from Gothenburg University and an Associate Professorship in Operations Management at Chalmers University of Technology. He is a Fellow of Faculty of the Institute of Management of Innovation and Technology.

\section{From success factors to company performance improvements}

How do we improve the performance of company R\&D and the development of process technology in particular? One possible approach is to identify good development behaviour of a more generic nature (often called best practice), condense this into a manageable number of what are often called 'success factors', and use them in the process of improving company performance. In this study of process development in process industry, success factors for process development have been developed and evaluated by R\&D managers in a survey of European Process Industry. The results are presented in two parts, of which this is the second.

\subsection{Introduction and summary of Part 1}

In the previously published Part 1 of this study, a classification system for success factors in $R \& D$ was developed and used in the development of success factors for process development in Process Industry. The use of a hierarchic system for classification of success factors was advocated in which the highest hierarchic level was called a strategic level, an underlying level was called a tactical level and the lowest level an operational level. The approach and terminology adopted were taken from QFD methodology and the structuring of customer needs [1]. In Part 1, success factors for process development were developed on a tactical level and their importance was examined in a survey of R\&D managers in European Process Industry. The empirical research results were presented with the research strategy, the sample and the conduct of the survey.

One conclusion from this part of the study was that success factors on a higher tactical level need to be further developed on an operational level to be more understandable and of better industrial use. Before we go into the details of the development of success factors on an operational level, let us first recapitulate the definition of the concept 'success factor', that was used in this study (for a full discussion on success factors we refer to Part 1). The following definition was presented to the respondents:

"In this context, we define 'success factors' in process development work as specific working methods and practices that lead to successful development projects (often called 'Best Practice' projects). The measure of success in development work and individual development projects may of course vary. In your assessment of the following potential success factors we would like you first to consider the importance of the selected success factor to future pay-back from the development, and then the importance of completing development on time at acceptable cost and meeting specified functional and quality criteria. Whether all these criteria for success need to be satisfied, or only some of them, naturally depends on the nature of the process development work." 
In the questionnaire that was sent to the R\&D managers, ten of the tactical success factors had an underlying level of operational success factors. The results from the respondents' ranking of those operational success factors will be presented in this paper, together with a new dynamic model for translation of success factors into performance indicators using the operational success factors.

\subsection{Dynamic model for translation of success factors into performance indicators}

When success factors for a company-specific task, e.g. process development, have been developed, they must be put into action and use before any actual improvements can be achieved and measured. Finding ways to facilitate the company's use of success factors is probably as important as finding the factors themselves. The terms 'best practice', 'success factors' and 'performance indicators' were discussed in Part 1 of this study.

It was first of all argued that it is important to identify what areas of company work need to be improved and to identify what kind of behaviour will do this, before a performance measuring system can be designed. The behaviour that needs to be improved can be condensed into a number of success factors, and after these success factors have been implemented in the company, the improvements can be measured by a number of performance indicators. We thus need to translate or relate success factors to performance indicators. This translation needs to be facilitated by some kind of tool. In a previous publication about success factors the use of a 'House of Quality' from the QFD methodology was suggested as one possible vehicle [2]. The principal rooms in such a House of Quality for success factors and performance indicators are outlined in Figure 1 below.

Figure 1 A 'house of quality' as a model for translation of success factors into performance indicators and for use in the company's implementation process. This is a simplified structural model which will be further developed at the end of this paper

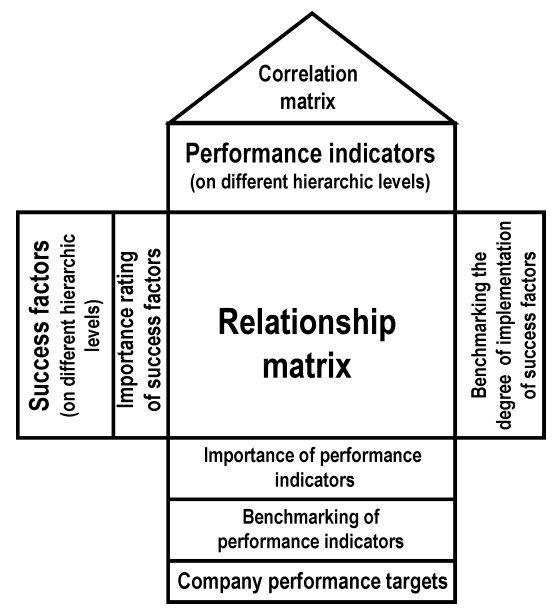

In a House of Quality, success factors can be related to performance indicators through the relationship matrix. The degree of implementation in the company can also be assessed in a benchmarking room to the right. The importance of individual success 
factors is also translated into the importance of individual performance indicators through the relationship matrix. The performance indicators can also be benchmarked and compared with company targets. This simplified structural model will be further developed at the end of this paper and the importance of its dynamic use will be advocated. But before we go into company use of the model, let us review the research results from ranking the operational-level success factors for process development.

\section{Summary of research methodology and treatment of research results}

For definitions of 'process development in process industry', the 'research approach' and 'methodology', the reader is referred to relevant sections of the previously published Part 1 of this study. Six categories of process industry were selected for this study: Mining and mineral industry, food and beverage industry, pulp and paper industry, chemical industry, industry for basic metal, and other process industry. It must be emphasised that all potential success factors were generated during interactive interviews and no other success factors have been added. For some tactical success factors that were generated in interviews with $R \& D$ managers and were presented in the previous part, a number of potential success factors on an operational level were also developed and presented to the respondents. The development of those success factors on an operational level was, as previously explained in Part 1, a completely 'bottom up' procedure insofar as no underlying operational success factors for any tactical success factor were included in the survey questionnaire unless those underlying factors had been identified as such in the interviews. The consequence of this strict methodology was that underlying operational success factors were assigned to only ten tactical success factors. Some success factors thus include two statements as a consequence of not wanting to change the wording of the success factors from the interviews with the respondents. Out of the 25 success factors on a tactical level, ten thus had underlying explanatory success factors on an operational level and the respondents were asked to rank these:

\footnotetext{
"For some success factors we also ask you to rank a number of factors that influence or contribute to these individual success factors. Please enter 1 in the square for the most important, 2 in the square for the second most important, etc."
}

The operational success factors can be seen as explanatory information for the tactical success factors (the tactical success factor can thus be seen as a summary of the underlying operational success factors). The success factors on a tactical level were rated on a five-point scale by the respondents, but the underlying operational success factors were ranked in order of importance. Ranking was preferred because of the limited number of alternatives and was intended to facilitate the total procedure for the respondents. In the treatment of the data from the survey, the number of respondents giving the highest ranking (ranking as no. 1; could also be called 'top of mind') for each success factor were counted. In the following presentation of the research results those figures have been entered in the tables under the heading 'total'. Since the total sample of process industries was categorised in six groups of industries, the results for each of these groups are also presented in each table. In each case the highest-ranking success factor is shown in bold type and the second highest in bold italic type. The same marking system has been used in the tables for the different categories of process 
industry. The operational success factors are presented in order of ranking, not in the order of presentation in the questionnaire.

\section{Presentation and discussion of the research results}

The operational success factors are presented below for the five areas of process development that were developed in Part 1:

- creating the development project

- working on the development project

- $\quad$ using the results

- internal environment

- external environment.

Only ten of the tactical success factors had underlying levels of operational success factors, as can be seen in the further presentation. The presentation of the research results has been integrated with the discussion. For each of the ten tactical success factors the wording of the tactical success factor is given first; this is followed by a presentation of the ranking results from the underlying operational success factors and a discussion of the research results.

\subsection{Creating the development project}

Tactical success factor no. 1: the development organisation is good at generating new ideas and formulating interesting new process development projects. (The ranking result for this success factor on a tactical level was 12).

Out of all underlying success factors on an operational level, the two highest ranked success factors were 'well formulated and clear technological visions that stimulate the imagination' and 'a clear and comprehensible problem description (preferably with the owner of the problem)'. The first success factor was ranked first by three categories of industry and the second ranked second by four categories.

Table 1 Ranking of success factors on an operational level for tactical success factor no. 1: the development organisation is good at generating new ideas and formulating interesting new process development projects

\begin{tabular}{|c|c|c|c|c|c|c|c|}
\hline $\begin{array}{l}\text { Success factors on an } \\
\text { operational level }\end{array}$ & Total & $\begin{array}{l}\text { Mining } \\
\quad \text { and } \\
\text { mineral } \\
\text { industry }\end{array}$ & $\begin{array}{c}\text { Food and } \\
\text { beverage } \\
\text { industry }\end{array}$ & $\begin{array}{c}\text { Pulp } \\
\text { and } \\
\text { paper } \\
\text { industry }\end{array}$ & $\begin{array}{l}\text { Chemical } \\
\text { industry }\end{array}$ & $\begin{array}{c}\text { Basic } \\
\text { metal } \\
\text { industry }\end{array}$ & Others \\
\hline $\begin{array}{l}\text { Well formulated and } \\
\text { clear technological } \\
\text { visions that stimulate } \\
\text { the imagination }\end{array}$ & 30 & 2 & 7 & 1 & 8 & 4 & 8 \\
\hline $\begin{array}{l}\text { A clear and } \\
\text { comprehensible } \\
\text { problem description } \\
\text { (preferably with the } \\
\text { owner of the problem) }\end{array}$ & 26 & 2 & 6 & 2 & 3 & 6 & 7 \\
\hline
\end{tabular}


Table 1 Ranking of success factors on an operational level for tactical success factor no. 1: The development organisation is good at generating new ideas and formulating interesting new process development projects (continued)

\begin{tabular}{|c|c|c|c|c|c|c|c|}
\hline $\begin{array}{l}\text { Success factors on an } \\
\text { operational level }\end{array}$ & Total & $\begin{array}{l}\text { Mining } \\
\text { and } \\
\text { mineral } \\
\text { industry }\end{array}$ & $\begin{array}{c}\text { Food and } \\
\text { beverage } \\
\text { industry }\end{array}$ & $\begin{array}{c}\text { Pulp } \\
\text { and } \\
\text { paper } \\
\text { industry }\end{array}$ & $\begin{array}{l}\text { Chemical } \\
\text { industry }\end{array}$ & $\begin{array}{c}\text { Basic } \\
\text { metal } \\
\text { industry }\end{array}$ & Others \\
\hline $\begin{array}{l}\text { Development needs } \\
\text { that are clearly } \\
\text { expressed by the } \\
\text { production } \\
\text { organisation }\end{array}$ & 23 & 4 & 2 & 1 & 8 & 3 & 5 \\
\hline $\begin{array}{l}\text { A recurring dialogue } \\
\text { and check of } \\
\text { development needs }\end{array}$ & 16 & 0 & 2 & 3 & 6 & 3 & 2 \\
\hline $\begin{array}{l}\text { Thorough discussion } \\
\text { and analysis of } \\
\text { alternative } \\
\text { development routes }\end{array}$ & 5 & 0 & 0 & 1 & 1 & 3 & 0 \\
\hline $\begin{array}{l}\text { A good in-depth } \\
\text { analysis of the } \\
\text { alternative } \\
\text { development problem }\end{array}$ & 4 & 1 & 1 & 0 & 1 & 1 & 0 \\
\hline Total & 104 & 9 & 18 & 8 & 27 & 20 & 22 \\
\hline
\end{tabular}

The importance of a strong capability of generating new ideas and projects has been proven and discussed in several publications, e.g. Von Hippel [3]. But how often are technological visions clear and well formulated in industry? Formulating a good technological vision is certainly the responsibility of the company management in its technology planning, and of the R\&D management in particular. Even more so for process development, since 'financing of long-term development work' was identified as an important success factor for process development (see tactical success factor no. 20). In a study of twenty projects in five companies, the most successful projects had a 'project guiding vision' [4]. Formulating a problem well is often said to be the first step towards solving it; this is true not only in academic research, but evidently also in industry. This could be something that each new project proposal or R\&D project should put more focus on. Both success factors are thus ranked as good drivers for the first step of the process development process.

\subsection{Working on the development project}

Tactical success factor no. 10: there are good incentives and driving forces for process development (the ranking result for this success factor on a tactical level was four).

Out of the underlying success factors on an operational level, the two highest ranked factors were 'the project has the support of top management' and 'a strong project manager (champion) with the energy to pursue long-term projects'. The first success factor was ranked first by all categories of industry, and the second was ranked second by five categories. This can be considered to be a remarkable consensus among all 
categories of industry. It must also be noted that the first success factor received more than twice as many points as the second.

Table 2 Ranking of success factors on an operational level for tactical success factor no. 10: there are good incentives and driving forces for process development

\begin{tabular}{|c|c|c|c|c|c|c|c|}
\hline $\begin{array}{l}\text { Success factors on } \\
\text { an operational level }\end{array}$ & Total & $\begin{array}{l}\text { Mineral } \\
\text { and mining } \\
\text { industry }\end{array}$ & $\begin{array}{c}\text { Food and } \\
\text { beverage } \\
\text { industry }\end{array}$ & $\begin{array}{l}\text { Pulp and } \\
\text { paper } \\
\text { industry }\end{array}$ & $\begin{array}{l}\text { Chemical } \\
\text { industry }\end{array}$ & $\begin{array}{c}\text { Basic } \\
\text { metal } \\
\text { industry }\end{array}$ & Others \\
\hline $\begin{array}{l}\text { The project has the } \\
\text { support of top } \\
\text { management }\end{array}$ & 58 & 7 & 10 & 5 & 11 & 14 & 11 \\
\hline $\begin{array}{l}\text { A strong project } \\
\text { manager } \\
\text { (Champion) with } \\
\text { the energy to pursue } \\
\text { long-term projects }\end{array}$ & 25 & 3 & 5 & 2 & 8 & 2 & 5 \\
\hline $\begin{array}{l}\text { The project has high } \\
\text { priority among other } \\
\text { development } \\
\text { projects }\end{array}$ & 12 & 0 & 2 & 0 & 3 & 3 & 4 \\
\hline $\begin{array}{l}\text { The company is } \\
\text { forced to produce } \\
\text { development results }\end{array}$ & 11 & 0 & 1 & 1 & 5 & 2 & 2 \\
\hline Total & 106 & 10 & 18 & 8 & 27 & 21 & 22 \\
\hline
\end{tabular}

Many studies of industrial excellence have emphasised the importance of top management support. Other studies argue strongly for the importance of top management support for product development, e.g. Roberts [5]. The point is often stressed to such an extent that one sometimes wonders whether anything at all can be accomplished without direct support from top management. Do we need a change of culture? We can now add process development to the long list of areas that need top management support. The second success factor includes two important aspects: not only the need for a champion, but for one who can pursue long-term projects. Is the combination of top management support and a champion a winning formula for driving process development projects too? In smaller projects, a single factor could be enough to supply sufficient driving force. The results fit very well with the results from previous research [5]. The other two less important success factors look like strong incentives at first glance, but this is obviously not the case.

Tactical success factor no. 12: the project group has a good and balanced composition (the ranking result for this success factor on a tactical level was 13).

Out of all the underlying success factors on an operational level, the two highest ranked factors were 'the group has a good balance between theoretical and practical people' and 'representatives from the production organisation are included'. The first of these was ranked first by five categories of industry, and the second was ranked second by four categories. It must also be noted that the first success factor has a clear margin to the second. 
The two highest ranked success factors state that the project group should include practical people (if we assume that production people are often gifted in practical matters).

Table 3 Ranking of success factors on an operational level for tactical success factor no. 12: the project group has a good and balanced composition

\begin{tabular}{lccccccc}
\hline $\begin{array}{l}\text { Success factors on } \\
\text { an operational level }\end{array}$ & Total & $\begin{array}{c}\text { Mineral } \\
\text { and mining } \\
\text { industry }\end{array}$ & $\begin{array}{c}\text { Food and } \\
\text { beverage } \\
\text { industry }\end{array}$ & $\begin{array}{c}\text { Pulp and } \\
\text { paper } \\
\text { industry }\end{array}$ & $\begin{array}{c}\text { Chemical } \\
\text { industry }\end{array}$ & $\begin{array}{c}\text { Basic } \\
\text { industry }\end{array}$ & Others \\
\hline $\begin{array}{l}\text { The project group } \\
\text { has a good balance } \\
\text { between theoretical } \\
\text { and practical people }\end{array}$ & 48 & 4 & 8 & 3 & 10 & 13 & 10 \\
$\begin{array}{l}\text { Representatives } \\
\text { from the production } \\
\text { organisation are } \\
\text { included }\end{array}$ & 33 & 4 & 6 & 5 & 6 & 3 & 9 \\
$\begin{array}{l}\text { The project group } \\
\text { has the ability to } \\
\text { handle innovators } \\
\text { and strong } \\
\text { personalities }\end{array}$ & 17 & 2 & 2 & 1 & 7 & 2 & 3 \\
$\begin{array}{l}\text { The project } \\
\text { includes members } \\
\text { with different types } \\
\text { of personalities }\end{array}$ & 7 & 0 & 1 & 0 & 4 & 2 & 0 \\
\hline \begin{tabular}{l} 
Total \\
\hline
\end{tabular} & 105 & 10 & 17 & 9 & 27 & 20 & 22 \\
\hline
\end{tabular}

The highest ranked success factor also stresses the aspect that the project group should include theoretical people. How often do project groups for process development include people with good theoretical knowledge? If the production organisation is responsible for process development, it is unlikely that there will be so many people with a strong theoretical background in project groups. Conversely, if process development is in the province of $R \& D$, there may not be so many practically oriented people.

If we consider the case study of the Chaparral Steel mini-mill, one characteristic is that there is a natural mix of practical and theoretical people [6]. The need to have a mix of practical and theoretical people in the technology transfer process is also highlighted by Knight [7]. The two other lower ranked success factors are of a 'softer' kind and relate to different personalities and how to handle strong personalities in projects. The importance of creating teams with different personalities has been discussed in many publications, e.g. [8]. But it must be noted that in this study this factor received only seven points, compared to the top ranked success factor which received 48 points.

Tactical success factor no. 14: effective monitoring of the project and its results from start to finish (the ranking result for this success factor on a tactical level was eight).

Out of all the underlying success factors on an operational level, the highest ranked factor was 'sufficient time spent on consideration and analysis at the decision points for milestones'. This factor was ranked first by five categories of industry (in mining and mineral industry there was clear support for 'monitoring of key surrounding issues'). 
Table 4 Ranking of success factors on an operational level for tactical success factor no. 14: effective monitoring of the project and its results from start to finish

\begin{tabular}{|c|c|c|c|c|c|c|c|}
\hline $\begin{array}{l}\text { Success factors on an } \\
\text { operational level }\end{array}$ & Total & $\begin{array}{l}\text { Mineral } \\
\text { and mining } \\
\text { industry }\end{array}$ & $\begin{array}{c}\text { Food and } \\
\text { beverage } \\
\text { industry }\end{array}$ & $\begin{array}{l}\text { Pulp and } \\
\text { paper } \\
\text { industry }\end{array}$ & $\begin{array}{l}\text { Chemical } \\
\text { industry }\end{array}$ & $\begin{array}{c}\text { Basic } \\
\text { metal } \\
\text { industry }\end{array}$ & Others \\
\hline $\begin{array}{l}\text { Sufficient time spent } \\
\text { in consideration and } \\
\text { analysis at the } \\
\text { decision points for } \\
\text { milestones }\end{array}$ & 47 & 2 & 6 & 4 & 14 & 11 & 10 \\
\hline $\begin{array}{l}\text { Careful monitoring } \\
\text { of 'key surrounding } \\
\text { issues' (including } \\
\text { new ones) during the } \\
\text { course of the project }\end{array}$ & 29 & 7 & 5 & 2 & 6 & 3 & 6 \\
\hline $\begin{array}{l}\text { Detailed analysis of } \\
\text { difficulties and } \\
\text { failures during the } \\
\text { project lifetime }\end{array}$ & 27 & 1 & 6 & 1 & 7 & 7 & 5 \\
\hline Total & 103 & 10 & 17 & 7 & 27 & 21 & 21 \\
\hline
\end{tabular}

Project analysis at set milestones is a main area of responsibility of the steering committee. How often do steering committee meetings allow enough time for in-depth discussions, and how often is the accumulated experience of the steering committee utilised in project work? There is a notion that steering committee meetings should be short and focused strictly on decisions. But ought this to be the case in complex R\&D projects?

One can also reflect that there is possibly too much written about the project group and too little about steering committees? The conclusion here is that careful analysis of project results at the milestones is a success factor if sufficient time is allocated!

Tactical success factor no. 16: the project is well communicated to the surrounding environment (the ranking result for this success factor on a tactical level was 16).

Table 5 Ranking of success factors on an operational level, for tactical success factor no. 16: the project is well communicated to the surrounding environment

\begin{tabular}{lccccccc}
\hline $\begin{array}{l}\text { Success factors on an } \\
\text { operational level }\end{array}$ & Total & $\begin{array}{c}\text { Mineral } \\
\text { and mining } \\
\text { industry }\end{array}$ & $\begin{array}{c}\text { Food } \\
\text { beverage } \\
\text { industry }\end{array}$ & $\begin{array}{c}\text { Pulp and } \\
\text { paper } \\
\text { industry }\end{array}$ & $\begin{array}{c}\text { Chemical } \\
\text { industry }\end{array}$ & $\begin{array}{c}\text { Basic } \\
\text { metal } \\
\text { industry }\end{array}$ & Others \\
\hline $\begin{array}{l}\text { The project is well } \\
\text { communicated in the } \\
\text { internal organisation } \\
\text { (understandable and } \\
\text { comprehensible) }\end{array}$ & 101 & 10 & 16 & 9 & 24 & 20 & 22 \\
$\begin{array}{l}\text { The project is well } \\
\text { communicated } \\
\text { externally (opening } \\
\text { new doors, attracting } \\
\text { development partners) }\end{array}$ & 5 & 0 & 1 & 0 & 3 & 1 & 0 \\
\hline Total & 106 & 10 & 17 & 9 & & & \\
\hline
\end{tabular}


Out of the two underlying success factors on an operational level, it is quite clear that the highest ranked factor was 'the project is well communicated in the internal organisation'. This factor was ranked first by all categories of industry. Support for this factor is overwhelming.

In the rich literature of project management the communication of the project is often discussed in terms of different directions of communication [9]. The ranking of the importance of internal communication compared to external communication makes sense, as it underlines that process development is more an internal affair. In product development there are a lot of communication interfaces between developer and customer, developer and other external project allies, etc., whereas in process development we are not concerned with a product launch but with an efficient internal technology transfer to production.

\subsection{Using the results}

No underlying operational success factors had been developed here.

\subsection{Internal environment}

Tactical success factor no. 20: the company has a good and stimulating climate for process development work (the ranking result for this success factor on a tactical level was seven).

Out of the underlying success factors on an operational level, the highest ranked factor was 'the company is also financing long-term development work'. The ranking points for this factor were more than twice as high as the other two. This factor was ranked first by all categories of industry. It is not possible to name a second success factor, and preferences within each category vary.

Table 6 Ranking of success factors on an operational level, for tactical success factor no. 20: the company has a good and stimulating climate for process development work

\begin{tabular}{|c|c|c|c|c|c|c|c|}
\hline $\begin{array}{l}\text { Success factors on } \\
\text { an operational } \\
\text { level }\end{array}$ & Total & $\begin{array}{l}\text { Mineral } \\
\text { and } \\
\text { mining } \\
\text { industry }\end{array}$ & $\begin{array}{l}\text { Food and } \\
\text { beverage } \\
\text { industry }\end{array}$ & $\begin{array}{l}\text { Pulp and } \\
\text { paper } \\
\text { industry }\end{array}$ & $\begin{array}{l}\text { Chemical } \\
\text { industry }\end{array}$ & $\begin{array}{l}\text { Basic } \\
\text { metal } \\
\text { industry }\end{array}$ & Others \\
\hline $\begin{array}{l}\text { The company is } \\
\text { also financing } \\
\text { long term } \\
\text { development work }\end{array}$ & 56 & 6 & 10 & 5 & 11 & 9 & 15 \\
\hline $\begin{array}{l}\text { Process developers } \\
\text { get recognition }\end{array}$ & 27 & 3 & 7 & 1 & 9 & 6 & 1 \\
\hline $\begin{array}{l}\text { The company } \\
\text { dares to embark on } \\
\text { projects involving } \\
\text { high risk }\end{array}$ & 21 & 1 & 1 & 2 & 6 & 5 & 6 \\
\hline Total & 104 & 10 & 18 & 8 & 26 & 20 & 22 \\
\hline
\end{tabular}


What do we mean by a good climate for development work? Three underlying success factors may well be too few to tap the dimension of a good climate for process development. One point to consider is that this question about a good climate might have been better answered by the R\&D staff than by the R\&D managers. The short-termism of company management is often discussed nowadays, but the influence it has on a company's working climate, especially on long-term activities like R\&D, is seldom seriously addressed by top management. Since this success factor puts the finger on the importance of a long-term $R \& D$ strategy for successful process development, it is a matter to seriously reflect upon. How does the research staff interpret all signals regarding fast payback, and is more visionary long-term thinking at R\&D departments stifled in its infancy because of this? One might have supposed that the two remaining success factors - recognition of process developers and willingness to undertake risk projects - should have ranked higher, because risk analysis is always preached. On the other hand, the low ranking is congruent with the attitude at the Chaparral Steel mini-mill, where risk-less projects are avoided because they do not have the potential to outperform the competition [6].

Tactical success factor no. 21: the development organisation includes individuals with suitable personal qualifications for process development work (the ranking result for this success factor on a tactical level was two).

Table 7 Ranking of success factors on an operational level for tactical success factor no. 21: the development organisation includes individuals with suitable personal qualifications for process development work

\begin{tabular}{|c|c|c|c|c|c|c|c|}
\hline $\begin{array}{l}\text { Success factors on } \\
\text { an operational } \\
\text { level }\end{array}$ & Total & $\begin{array}{l}\text { Mineral } \\
\text { and } \\
\text { mining } \\
\text { industry }\end{array}$ & $\begin{array}{l}\text { Food and } \\
\text { beverage } \\
\text { industry }\end{array}$ & $\begin{array}{l}\text { Pulp and } \\
\text { paper } \\
\text { industry }\end{array}$ & $\begin{array}{l}\text { Chemical } \\
\text { industry }\end{array}$ & $\begin{array}{l}\text { Basic } \\
\text { metal } \\
\text { industry }\end{array}$ & Others \\
\hline $\begin{array}{l}\text { Ability to } \\
\text { distinguish what is } \\
\text { important from } \\
\text { what is not }\end{array}$ & 38 & 2 & 4 & 7 & 7 & 10 & 8 \\
\hline $\begin{array}{l}\text { Strong belief in the } \\
\text { project }\end{array}$ & 32 & 4 & 8 & 1 & 10 & 3 & 6 \\
\hline $\begin{array}{l}\text { A wish to try and } \\
\text { test new things }\end{array}$ & 16 & 2 & 4 & 0 & 4 & 1 & 5 \\
\hline Curiosity & 6 & 0 & 1 & 0 & 3 & 2 & 0 \\
\hline $\begin{array}{l}\text { Patience and } \\
\text { persistence }\end{array}$ & 6 & 1 & 1 & 0 & 1 & 2 & 1 \\
\hline Fearlessness & 3 & 0 & 0 & 0 & 2 & 0 & 1 \\
\hline $\begin{array}{l}\text { Ability to } \\
\text { communicate } \\
\text { expertise }\end{array}$ & 3 & 1 & 0 & 0 & 0 & 2 & 0 \\
\hline $\begin{array}{l}\text { Not too much } \\
\text { operational } \\
\text { involvement in } \\
\text { production matters }\end{array}$ & 2 & 0 & 0 & 0 & 0 & 1 & 1 \\
\hline Total & 106 & 10 & 18 & 8 & 28 & 21 & 22 \\
\hline
\end{tabular}


Out of all underlying success factors on an operational level for this success factor on a tactical level, the two highest ranked factors were 'ability to distinguish what is important from what is not' and 'strong belief in the project'. The first operational success factor was ranked first by three categories of industry, while the second was ranked second by two and first by three. Except for the factor ranked third, 'a wish to try and test new things', one could say that the rest got a very low ranking.

What is a suitable personality for R\&D and process development in particular? What criteria are used in the recruitment process for the R\&D staff? The underlying success factors are probably too few to capture this complex tactical success factor, but they could be a good starting point for further research.

The individual's professional knowledge is not considered here, but is an area that should not be neglected in further development of company success factors. There is good agreement between different categories of industry. The top ranked success factor - ability to identify what is important - certainly merits further thought, particularly about the true nature of that ability. Is this an important personal qualification for process development in particular, and what kind of ability are we talking about more specifically? A strong belief in the project is an interesting aspect to consider when setting up new project teams. Do the project members really have a strong belief in their project? This is an area that merits further investigation in the context of R\&D in general.

\subsection{External environment}

Tactical success factor no. 23: the development organisation is good at creating and engaging in development collaborations and alliances (the ranking result for this success factor on a tactical level was 21).

Table 8 Ranking of success factors on an operational level for tactical success factor no. 23: the development organisation is good at creating and engaging in development collaborations and alliances

\begin{tabular}{|c|c|c|c|c|c|c|c|}
\hline $\begin{array}{l}\text { Success factors on an } \\
\text { operational level }\end{array}$ & Total & $\begin{array}{l}\text { Mineral } \\
\text { and mining } \\
\text { industry } \\
\end{array}$ & $\begin{array}{l}\text { Food and } \\
\text { beverage } \\
\text { industry }\end{array}$ & $\begin{array}{l}\text { Pulp and } \\
\text { paper } \\
\text { industry }\end{array}$ & $\begin{array}{l}\text { Chemical } \\
\text { industry }\end{array}$ & $\begin{array}{c}\text { Basic } \\
\text { metal } \\
\text { industry }\end{array}$ & Others \\
\hline $\begin{array}{l}\text { Attractiveness as a } \\
\text { partner for } \\
\text { collaboration in the } \\
\text { selected project }\end{array}$ & 61 & 3 & 11 & 6 & 19 & 10 & 12 \\
\hline $\begin{array}{l}\text { Well defined roles } \\
\text { and division of } \\
\text { responsibilities in the } \\
\text { collaborative project }\end{array}$ & 30 & 7 & 5 & 1 & 6 & 7 & 4 \\
\hline $\begin{array}{l}\text { A well balanced share } \\
\text { of risks between } \\
\text { individual } \\
\text { collaboration partners }\end{array}$ & 9 & 0 & 1 & 1 & 1 & 1 & 5 \\
\hline $\begin{array}{l}\text { An attractive portfolio } \\
\text { of other development } \\
\text { projects }\end{array}$ & 7 & 1 & 1 & 0 & 1 & 3 & 1 \\
\hline Total & 107 & 11 & 18 & 8 & 27 & 21 & 22 \\
\hline
\end{tabular}


Out of all four underlying success factors on an operational level, the two highest ranked factors were 'attractiveness as a partner for collaboration in the selected project' followed by 'well defined roles and division of responsibilities in the collaborative project'. The first success factor was ranked first by five categories of industry, and the second was ranked second by four categories and first by one. The highest ranked success factor got twice as high a ranking compared to the second highest, which in turn got three times as high ranking as the third.

The clear case of the top ranked success factor - being an attractive partner - also has a bearing on the second success factor, because well defined but different roles may be a success concept in collaboration and alliances in general.

Tactical success factor no. 24: good and well-functioning networks are available for research and technical development (the ranking result for this success factor on a tactical level was 18).

Table 9 Ranking of success factors on an operational level, for tactical success factor no. 24: good and well-functioning networks are available for research and technical development

\begin{tabular}{lccccccc}
\hline $\begin{array}{l}\text { Success factors } \\
\text { on an operational } \\
\text { level }\end{array}$ & Total & $\begin{array}{c}\text { Mineral and } \\
\text { mining } \\
\text { industry }\end{array}$ & $\begin{array}{c}\text { Food and } \\
\text { beverage } \\
\text { industry }\end{array}$ & $\begin{array}{c}\text { Pulp and } \\
\text { paper } \\
\text { industry }\end{array}$ & $\begin{array}{c}\text { Chemical } \\
\text { industry }\end{array}$ & $\begin{array}{c}\text { Basic } \\
\text { metal } \\
\text { industry }\end{array}$ & Others \\
\hline $\begin{array}{l}\text { Machine } \\
\text { manufacturers } \\
\text { and equipment } \\
\text { suppliers }\end{array}$ & 35 & 2 & 10 & 6 & 7 & 5 & 5 \\
$\begin{array}{l}\text { Universities and } \\
\text { institutes of } \\
\text { technology }\end{array}$ & 23 & 2 & 4 & 0 & 8 & 4 & 5 \\
$\begin{array}{l}\text { External } \\
\text { development } \\
\text { companies and } \\
\text { research institutes }\end{array}$ & 22 & 2 & 2 & 0 & 6 & 9 & 3 \\
$\begin{array}{l}\text { Raw material } \\
\text { suppliers }\end{array}$ & 12 & 2 & 1 & 2 & 2 & 1 & 4 \\
$\begin{array}{l}\text { Engineering } \\
\text { companies }\end{array}$ & 12 & 3 & 0 & 0 & 2 & 3 & 4 \\
$\begin{array}{l}\text { Reagent } \\
\text { manufacturers }\end{array}$ & 1 & 0 & 0 & 0 & 1 & 0 & 0 \\
\hline Total & 105 & 11 & 17 & 8 & 26 & 22 & 21 \\
\hline
\end{tabular}

The picture is not so clear for this success factor. Out of all six underlying success factors on an operational level, the highest ranked factor was 'networks with machine manufacturers and equipment suppliers', with 'networks with universities and institutes of technology' and 'external development companies and research institutes' in second and third place, respectively. The first success factor was ranked first by four categories of industry. 
For companies in Process Industry, the importance of collaborating with equipment manufacturers is well proven in other studies, e.g. Hutcheson et al. [10]. It can be noted that the importance of strong collaboration with equipment suppliers is recognised especially by food and beverage industry and pulp and paper industry. The importance of collaborating with research institutes is also a fact well known to professionals in basic metal industry.

Tactical success factor no. 25: the development organisation has good knowledge of conditions in the industry and its external business environment (the ranking result for this success factor on a tactical level was 11).

This is the only tactical success factor out of all ten where it is not possible to single out the most important operational factor. It is also interesting that there is a widespread in the results within each category of industry.

Table 10 Ranking of success factors on an operational level for tactical success factor no. 25: the development organisation has good knowledge of conditions in the industry and its external business environment

\begin{tabular}{|c|c|c|c|c|c|c|c|}
\hline $\begin{array}{l}\text { Success factors on } \\
\text { an operational level }\end{array}$ & Total & $\begin{array}{l}\text { Mineral } \\
\text { and } \\
\text { mining } \\
\text { industry }\end{array}$ & $\begin{array}{c}\text { Food and } \\
\text { beverage } \\
\text { industry }\end{array}$ & $\begin{array}{l}\text { Pulp and } \\
\text { paper } \\
\text { industry }\end{array}$ & $\begin{array}{l}\text { Chemical } \\
\text { industry }\end{array}$ & $\begin{array}{c}\text { Basic } \\
\text { metal } \\
\text { industry }\end{array}$ & Others \\
\hline $\begin{array}{l}\text { Good knowledge of } \\
\text { production structure } \\
\text { and market } \\
\text { conditions in the } \\
\text { industry }\end{array}$ & 39 & 2 & 8 & 2 & 11 & 6 & 10 \\
\hline $\begin{array}{l}\text { Good knowledge of } \\
\text { the external } \\
\text { infrastructure for the } \\
\text { process in question } \\
\text { (raw materials, } \\
\text { energy) }\end{array}$ & 33 & 4 & 7 & 3 & 7 & 6 & 6 \\
\hline $\begin{array}{l}\text { Knowledge of } \\
\text { competitors' } \\
\text { production } \\
\text { technology and } \\
\text { production } \\
\text { environment }\end{array}$ & 33 & 4 & 3 & 3 & 8 & 9 & 6 \\
\hline Total & 105 & 10 & 18 & 8 & 26 & 21 & 22 \\
\hline
\end{tabular}

This subject is often discussed nowadays in relation to company systems for information search and retrieval (business intelligence). The character of the success factor and the underlying success factors on an operational level are of a kind that make them more important for innovative process development than for incremental development [2].

\subsection{Final discussion of research results}

The lack of previously presented success factors for process development was discussed in Part 1 of this study, which emphasised the exploratory character of this 
study. The ranking and rating of success factors should consequently be used more as guidelines for recognising trends in data than for making strict absolute comparisons of importance. The method of including only potential success factors from the interviews, and letting the rating and ranking of $R \& D$ managers decide what are success factors, was intended to avoid any subjective evaluations from the researcher in the research process. It must also be observed that only 10 out of 25 tactical success factors had underlying operational success factors. It must also be noted that although a majority of the respondents selected one operational success factor as the most important, some other success factors often received a fair share of top ranking points.

A company that is developing success factors should therefore carefully consider all alternative success factors. The ranking of the operational success factors has given some interesting answers, but as usual generated even more questions to be answered.

A picture of process development and the process development process is gradually emerging from the research results. The ranking of the operational success factors has given a better understanding of areas of importance for related tactical success factors. The operational success factors are thus of interest, but the lack of operational success factors for certain tactical factors is even more so. The area called 'using the results from process development', which stood out as an important area for process development in the rating, did not get any underlying operational success factors at all in the process of developing success factors with the R\&D managers. This can be interpreted to mean that the technology transfer process was not at the front of R\&D managers' minds during the interviews, and possibly not even in their management of $R \& D$. The conclusion is that this part of the process development process presented in Part 1 is probably not getting enough attention.

In the perspective of previously presented success factors on a tactical level together with the success factors on an operational level, the results indicate that process development and the process development process differ from product development and the product development process. It cannot be assumed that this list of success factors contains all important success factors for process development, but it is reasonable to argue that it provides a good starting point for the further development of a better and more complete list of such factors. The rating and ranking of the results should be treated with care. The generalisation of research findings, often called the external validity, is related to how far the results from this study are valid for process industry in general. The results from the rating of success factors on a tactical level, presented in Part 1, showed quite good agreement between the six different categories of industry. The ranking of the operational success factors also often showed remarkable agreement between the six categories of process industry. The combined results support the belief that the success factors developed in this study are of a generic nature for process industry.

\section{Theoretical consideration of success factors and performance indicators}

Identification of success factors for different company functions is only one step on the road to company performance improvements. Implementation of success factors in the company working environment is an issue of equal importance, and a part that can be described as the company's 'performance improvement process'. 


\subsection{A company performance improvement process}

There are presumably many alternative ways to improve a company's performance, and there is a spectrum of different approaches, from very informal to structured and formal. At the Chaparral steel mini-mill, process improvements are immediately enacted, without waiting for management approval or standardisation of 'best practice': if it works, it is de facto standard [6]. Process improvement implementation at AT\&T is on the other hand an example of a highly structured and formal performance improvement process [11]. One cannot transfer a performance improvement process from one company to another without first considering whether it will suit that particular company's characteristics such as size, culture, and type of industry.

The process of implementing success factors into a company's daily life, and the need to measure the improved performance for further feedback, have been discussed thoroughly in several publications on process management. A process model for improving company productivity is given by Sink [12], and in an attempt to apply this to success factors for R\&D a similar process has been discussed by Lager and Hörte [2]. The process of developing performance measures for $R \& D$ has been treated by several authors; for an extensive treatment of this issue and a comprehensive list of alternative performance indicators for $\mathrm{R} \& \mathrm{D}$, see for example $[13,14]$. A more formal performance improvement process is the point of departure in the following text, because a less formal process can be more easily derived from a formal process. A formal process could include the following six main steps:

- development of company success factors

- development of performance indicators

- measuring performance

- implementation of success factors in company work processes

- measuring performance

- feedback.

We will not discuss this total performance improvement process further, but focus on the first steps, viz. the development of success factors and how to translate them into performance indicators.

\subsection{Success factors and performance indicators}

Inherent in the concept of success factors is a notion that if success factors are implemented in the company, the company will be successful, or in other words its performance will be improved. Success factors can thus be looked upon as individual independent variables influencing the dependent variable 'success'. We thus assume some sort of causal relationship between implemented success factors and improved performance in the company. The relationship is illustrated in Figure 2. 
Figure 2 A graphic illustration of how the implementation of a number of success factors in different company functions influences the dependent variable functional performance. Improved performance in individual functions is also assumed to influence the company's overall performance

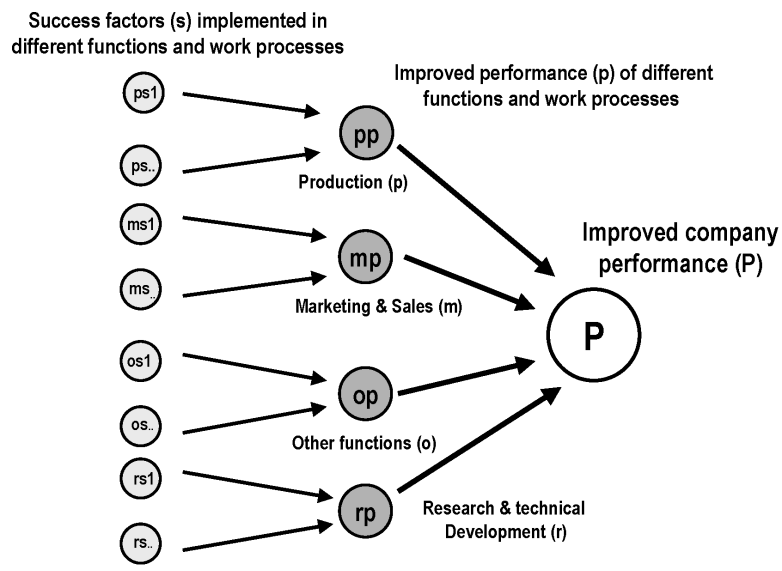

One problem with 'research on research' is that R\&D is only one of several company functions that are involved in the development of products and processes. It is the company's aggregated performance in $\mathrm{R} \& \mathrm{D}$, production, marketing and sales, etc. that influences performance in the development of new products and processes. If we measure performance improvements on a company level, the dependent variable of ultimate interest, we cannot assume that improved overall performance is attributable to $R \& D$ success alone: other units of the company may also have made significant contributions. Successful implementation of success factors for, say, R\&D, or part of the R\&D function like process development, is only one performance improvement that will affect the company's overall performance.

It is not only individual success factors that vary in their importance to the improvement of a department's performance; the importance ratings of success for other parts of the company and the total synergy and optimisation of company resources for best performance cannot be ignored. To conclude, and referring also to the discussion of research strategy in Part 1 , it is not easy to prove causal dependency between implemented success factors and overall company performance improvements.

\subsection{Importance ratings and implementation of success factors}

In Part 1 of this study it was argued that company success factors should be developed on different hierarchic levels and that success factors must be developed down to an operational level to understand how they could be improved and measured. It was also advocated that identification of success factors is not enough, and that a rating of their individual importance is an equally important step. The importance ratings presented in studies of other companies can be used as guidelines, but the uniqueness of each company must influence the importance ratings, so the importance of potential success factors should consequently also be rated by each company. The importance rating of an individual success factor can also be viewed as a dependent variable influenced by a number of independent variables. 
Importance rating of success factor $=f(a, b, c \ldots \ldots)$

$a=$ type of work

$b=$ type of industry (sub-category)

$c=$ company business environment

When the importance of success factors has been rated by a company, the ratings could also be used to prioritise the implementation of individual success factors. After the implementation process has started, the degree of implementation is a function of time and how well the implementation is carried out. How well a success factor is implemented can be assessed by internal benchmarking.

\subsection{Performance improvements and performance indicators}

Performance can be measured with different degrees of accuracy and through different kinds of measures. A performance indicator is a measure of some kind of performance. The term indicator implies that sometimes we cannot measure the variable directly, but only indirectly; we assume that there is some sort of a correlation. The relationships between performance indicators and success factors are not likely to follow a simple pattern.

Performance of a company activity $=f(a, b, c \ldots)$

$a=$ the company's importance rating of a success factors related to this activity

$b=$ the degree of implementation of a success factor related to this activity

Like success factors, performance can be measured on different hierarchic levels, and it is argued here that performance indicators should likewise be developed on different hierarchic levels. The classification of performance measurements into internal and external categories is well described by Schumann et al. [15]. The performance measurements related to success factors on a tactical level, for example, are measurements that are related to efficiency improvements and are thus measurements of internal efficiency. Performance measurements on a higher hierarchical level relate to a more strategic level of success factors like 'good process development'; at that level they may be more related to effectiveness and can consequently better be measured on an output level of process development.

\section{From success factors to company performance improvements: further development of an operational model for relating success factors to performance indicators}

The need for a tool to translate success factors into performance indicators was expressed in the introduction of this paper. The use of an already accepted company tool for such a translation was suggested, and the use of a 'House of Quality' from the QFD methodology was proposed. The House of Quality can nowadays be considered as not only an efficient tool for product and process development, but a tool of a more general nature that is especially suited for relational data and for company use in benchmarking. For a general introduction to the methodology see [16], and for its application in Process Industry [17]. A simplified model was presented in Figure 1, and in Figure 3 this model has been further developed into a real House of Quality. The foregoing theoretical 
discussions will be one point of departure in the discussions of the functionality of the individual rooms. In Figure 3, three success factors for process development have been selected to illustrate the translation into performance indicators. The numbers in the figure are only tentative examples to illustrate the use of individual rooms; they are not based on any specific company case.

Figure 3 A 'House of Quality' for the translation of success factors into performance indicators. Three tactical success factors have tentatively been selected to illustrate the use of the model. Success factors on an operational level have been used in the development of performance indicators

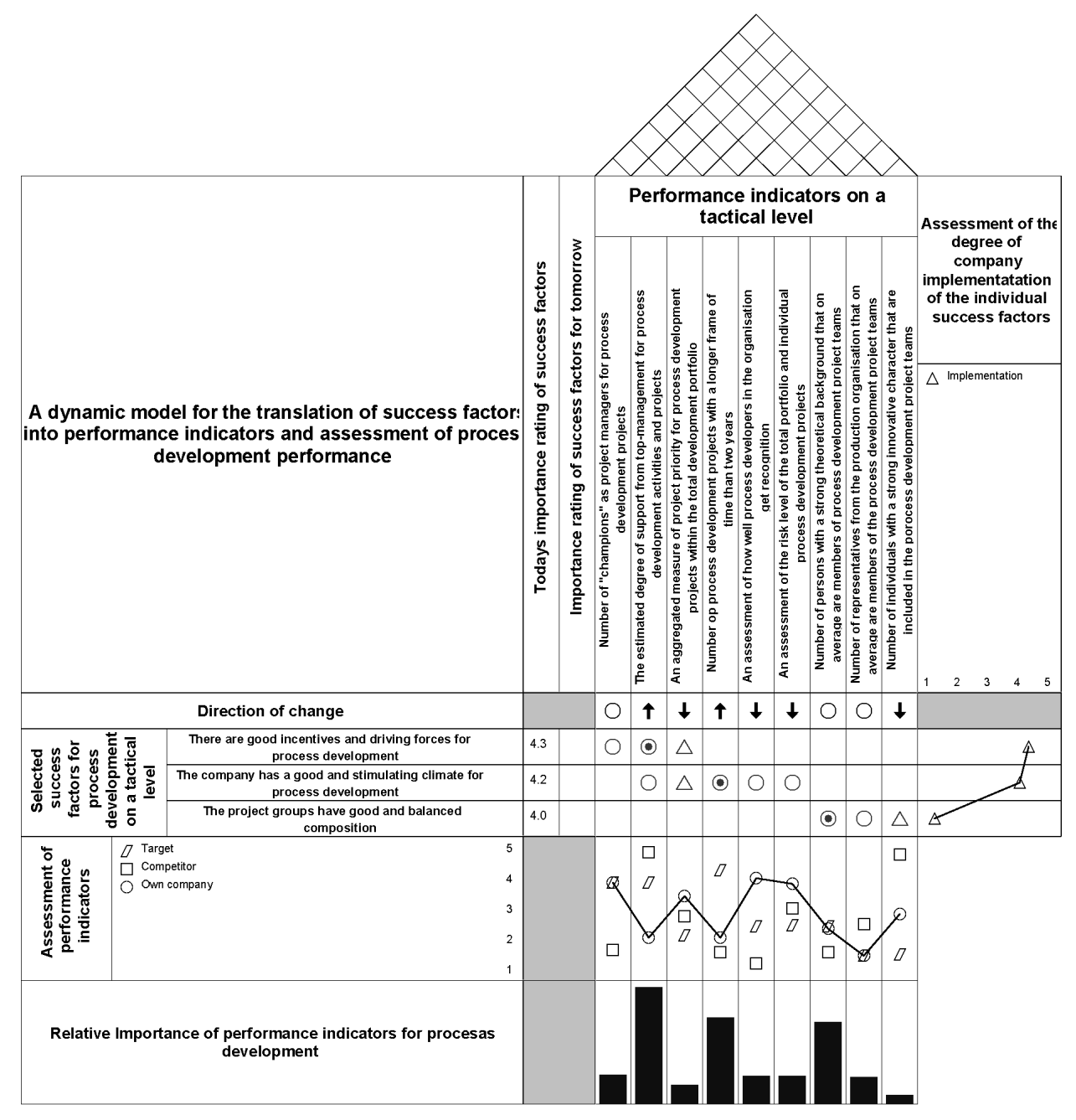

\subsection{Building a hierarchy of success factors on different levels}

The three success factors are introduced in the left room of Figure 3. In usual QFD terminology this is called the 'WHAT' room, where customer demands are normally presented. In the present case only the three selected success factors for process 
development are shown for demonstration purposes, but all 25 success factors from the study could of course have been included here.

\subsection{Rating the importance to the company of individual success factors}

Two importance rating rooms have been included to the right of the success factors. The first one, where figures for importance are given, is a room where the company's importance ratings of individual success factors should be introduced. The figures are from this survey, but it is recommended that each company should put in its own figures from an internal importance rating. We will come back to the second room for importance rating in a later section on the time dependence of importance ratings.

\subsection{Benchmarking the degree of company implementation of individual success factors}

Success factors that have been chosen by the company must be implemented in its work processes. The degree of implementation can be assessed by internal bechmarking, and a room for that is included to the right of the relationship matrix in Figure 3.

\subsection{Measuring the results of implemented success factors by a number of performance indicators}

Performance must be measured to be able to give feedback for the performance improvement process. On top of the relationship matrix, performance indicators have been developed and introduced in vertical columns in the room usually called the 'HOW' room. In this room product properties are normally presented, but in this case performance indicators have been developed and introduced here using the success factors on an operational level that are presented in this part of the study.

\subsection{Translating importance of success factors into importance of performance indicators with a relationship matrix}

It has been previously mentioned that the relation between success factors and performance indicators does not necessarily follow a simple pattern. The relationship matrix in a House of Quality is thus a suitable tool for this purpose, because the total relational pattern between performance indicators and success factors can be captured. Different symbols represent different degrees of strength of the individual relations (the double ring is usually a nine, a single ring a three and a triangle one). The importance ratings for each success factor are multiplied by the strength of each relation in the relationship matrix, and the accumulated sum for each performance indicator is presented in a room in the bottom of the house. The importance of success factors is thus translated into the importance of the performance indicators, which can be used in the further analysis of company performance and for setting targets. 


\subsection{Benchmarking performance with selected external competitors and setting targets for performance indicators and direction of change}

The performance that is measured with an instrument on a selected scale can also be benchmarked against competitors; a room for that is included in the bottom of the house.

The company can set individual targets for each performance indicator. These targets indicate the direction of change relative to present performance. The direction of change is also explicitly given in a room below the performance indicators, where an upward-pointing arrow indicates that improvement is needed, a downward-pointing arrow indicates that performance can be reduced, and a circle that it should stay as it is.

\subsection{A dynamic view of success factors and performance improvements}

This section started with a theoretical consideration of success factors and performance indicators. We will now end it by considering the matter from another perspective. 'Success factors for whom and for what?' were questions asked in Part 1 of this study. It is now time to ask 'when?'. Will success factors and performance indicators from yesterday, today and for tomorrow be the same? We come back to the question that was posed at the beginning of Part 1 of this study, i.e. whether the behaviour and success factors of today will be equally important tomorrow. Company behaviour and specific know-how, often called 'core skills', are likely to change over time. The concept of 'core capabilities' or 'core skills' is usually defined as competitive knowledge or behaviour which is not public, which has been acquired by a company over an extended period of time, and which is not available to competitors in the business. For a full treatment of the subject, see [18].

The strength of nurturing core capabilities may however have the opposite effect and turn them into 'core rigidities'. Core rigidities are thus 'good old core capabilities' that are no longer important and may even be harmful to the company in the future. There are several examples of such cases; the subject has been thoroughly treated by Leonard-Barton [4]. Thus if successful company behaviour changes over time, it is reasonable to assume that success factors that lead to this behaviour should also change over time. Because the importance rating of company success factors is a function of time, there is a need to re-evaluate success factors on a regular basis; importance ratings and performance measures should be revised and if necessary adjusted.

This is further illustrated in Figure 3 in the second room for importance rating, called 'importance rating for tomorrow'. Updating the importance rating of success factors is an important step to prevent 'core capabilities' from becoming 'core rigidities'. Not only should the importance ratings of already selected success factors and the targets for performance indicators be adjusted, but obsolete success factors and performance indicators should be removed and new ones added. Making this revision on a regular basis will make the success factors dynamic and help to achieve the gradual evolutionary adjustment that is recommended as preferable to revolutionary change [4].

\section{Further research}

In this study success factors for process development have been developed. The study has generated many answers but also more questions. In the running text many questions 
have been posed during the discussions of the research results and they can be embryos for further research areas. No operational success factors in the area of technology transfer were spontaneously recorded during the interviews. Since the rating of success factors on a tactical level indicates the importance of technology transfer in process development, the question 'What are the operational success factors for internal technology transfer in process development?' would appear to be a suitable subject for further research.

The implementation process for success factors is another interesting avenue for further research that has only been touched upon in this study. The word 'implementation' is not a very good word because it gives an impression of one-way communication or something of a 'top down' process. Successful use of success factors and performance indicators in $\mathrm{R} \& \mathrm{D}$ probably needs to be more in the nature of two-way communication, and the development of success factors and the rating of success factors are a process that should be undertaken jointly by the whole organisation.

\section{Conclusions}

The ranking of the operational success factors underlying the tactical success factors has given a better understanding of areas of importance for process development. The results from this part of the study, combined with the results from Part 1, give a better understanding of the nature of process development. The results point to a development area, a development process and a development behaviour that are quite different from product development and the product development process.

As not so much research has been undertaken in this area, the results can also provide one possible starting point for further research. The previous publication, Part 1 of this study, started with the development of a general classification system for success factors, and it was advocated that their contextual dependencies should be taken more into account.

This part of the study ends with the development of a model for the translation of success factors into performance indicators. It is argued that the use of success factors and performance indicators can be facilitated by such a model, and that the use of such a model will improve the performance improvement process. The dynamic use of importance ratings of success factors will make the gradual renewal of company core skills smoother and more firmly based on fact.

\section{Acknowledgements}

This work has been partly financed by Kempestiftelserna; their financial support is gratefully acknowledged. Thanks are due to Gunilla Bergdahl for research assistance and help with the survey. Input from discussions with R\&D management staff in Process Industry is highly appreciated. We also sincerely thank all companies who participated in this survey. Special thanks are also due to industry representatives and other persons who substantially helped to improve this paper. 


\section{References}

1 Griffin, A. and Hauser, J.R. (1991) The Voice of the Customer, Working Paper No. 56-91, Massachusetts Institute of Technology.

2 Lager, T. and Hörte, S.A. (2000) 'Critical success factors for improvement and innovation of process technology in process industry', Proceedings of the 3rd International (Euro) CINet Conference, CI 2000: From Improvement to Innovation, September, Aalborg University, Denmark.

3 Von Hippel, E. (1988) The Sources of Innovation, Oxford University Press.

4 Leonard-Barton, D. (1995) Wellsprings of Knowledge, Harvard Business School Press.

5 Roberts, E.B. (1995) 'Benchmarking the strategic management of technology', Research Technology Management, Vol. 38, No. 1, pp.44-56.

6 Leonard-Barton, D. (1992) 'The factory as a learning laboratory', Sloan Management Review, Fall, Vol. 34, No. 1, pp.23-38.

7 Knight, K.E. (1984) 'Technology transfer in the petroleum industry', Journal of Technology Transfer, Vol. 8, No. 2, pp.27-34.

8 Belbin, R.M. (1993) Management Teams: Why They Succeed or Fail, Butterworth-Heinemann, Oxford.

9 Briner, W., Geddes, M. and Hastings, C. (1990) Project Leadership, Gower.

10 Hutcheson, P., Pearson, A.W. and Ball, D.F. (1996) 'Sources of technical innovation in the network of companies providing chemical process plant and equipment', Research Policy, No. 25, pp.25-41.

11 AT\&T (1988) Process Quality Management \& Improvement Guidelines (PQMI), AT\&T Quality Library Books, Indianapolis.

12 Sink, S.D. (1985) Productivity Management, John Wiley \& Sons, New York.

13 Kerssens-Van Drongelen, I.C., (1999) Systematic Design of R\&D Performance Measurement Systems, Thesis, University of Twente, Enschede, The Netherlands.

14 Kerssens-Van Drongelen, I.C., Nixon, B. and Pearson, A.W. (2000) 'Performance measurement in industrial R\&D', International Journal of Management Reviews, Vol. 2, No. 2, pp.111-145.

15 Schumann, Jr. P.A., Ransley, D.L. and Prestwood, D.C.L. (1995) 'Measuring R\&D performance', Research Technology Management, Vol. 38, No. 3, pp.45-54.

16 Day, R.G. (1993) Quality Function Deployment - Linking a Company with its Customers, Quality Press.

17 Tottie, M. and Lager, T. (1995) 'QFD - linking the customer to the product development process as a part of the TQM concept', $R \& D$ Management, Vol. 25, No. 3, pp.257-267.

18 Hamel, G. and Heene, A. (1994) Competence Based Competiton, John Wiley \& Sons Ltd. 